\title{
Human Security in Practice: The Chinese Experience
}

\author{
Ren Xiao
}

\subsection{INTRODUCTION}

Human security was defined as freedom from want, freedom from fear, and the centrality of dignity by the Commission on Human Security (2003). This was subsequently endorsed by the United Nations (UN) General Assembly when it referred to the "right of people to live in freedom and dignity" (UNGA 2012). Although the actual term "human security" (人的安全 in Chinese) has not been widely used thus far, similar ideas or practices have been flourishing in China. In response to the questions underlying the emergence of human security norms, this chapter attempts to elaborate on China's experience and progress with regard to human security by, respectively, dealing with three major issues, namely, how the idea of human security is understood or defined by the government and social actors; the ways in which the distinctions between the "protection" and "empowerment" aspects of human security are understood and accepted; and what particular downside risks

R. Xiao $(\bowtie)$

Institute of International Studies, Fudan University, Shanghai, China e-mail: renxiao2006@fudan.edu.cn

(C) The Author(s) 2019

Y. Mine et al. (eds.), Human Security Norms in East Asia, Security, Development and Human Rights in East Asia, https://doi.org/10.1007/978-3-319-97247-3_3 
are perceived as pressing human security issues in China. The chapter concludes with a discussion of the overall human security practices and shows that, based on current indicators, China is heading in a healthy direction in terms of promoting human security.

\subsection{The Understanding of Human Security IN CHINA}

\subsubsection{A New Consensus}

In China, the government is often wary of new academic terms and tends to avoid using them directly. However, the findings from our previous study (Ren and Li 2013) clearly showed that the country is following a trajectory of increasingly attaching more importance to human (both individual and collective) security. Much greater attention has been paid to mitigating threats to human security, and practical measures are being taken to fulfill the mandate. We emphasized the convergence of the human security idea and China's practices (Ren and Li 2013). Our findings disprove the following statement: "the very notion of 'human security' has so far not appeared in the Chinese language in any possible translation, and the People's Republic of China (PRC) has not even accepted or adopted the concept of human security in either domestic development papers or foreign policy guidelines..." (Wu 2013, 1). Our examination suggests otherwise. Though the Chinese government has only used the term "human security" on a few occasions, China is definitely engaged in the enterprise of enhancing human security.

The fact that China is becoming more open and receptive to human security is strongly related to its experience within the UN system. As one of the five permanent members of the UN Security Council, China has long been supportive of the UN, the most important international organization in today's world, and the country has played a proactive role in various UN activities such as peacebuilding, development, and global governance (Breslin and Ren 2018). Over the years, the UN has been subjected to criticisms and it is widely believed that reforms are needed, which China supports. Nevertheless, Beijing continues to show a belief that the UN plays an irreplaceable role in global governance, and China has endeavored to support this by encouraging the UN to play its role well (Kim 1999). This has remained an unchanged priority in China's foreign policy agenda. 
China's steady backing has boosted the status of the UN in world affairs, at a time when the world is faced with growing global challenges in the first decades of the twenty-first century. Meanwhile, the UN has taken the lead in advocating and/or spreading norms and principles, and this has affected and helped to shape China's ideas (Kent 2014). Usually, UN initiatives or proposals attract China's attention, and prompt Beijing to have a closer look at them before taking actions to adapt to the new norms or principles (Morton 2009, 75-76). For example, China was involved in the deliberations and adoption of the UN World Summit Outcome Document in 2005. Although it is not the same thing as the "responsibility to protect" idea proposed by the International Commission on Intervention and State Sovereignty (ICISS 2001), to some extent the Outcome Document is consistent with this idea in terms of thinking on protection. The Outcome Document attempts to strike a balance between the need to protect innocent people around the world from being harmed while avoiding the abuse of external intervention or selfish behavior in the name of protection. For this, the Outcome Document imposes limitations by listing four specific crimes against which the international community should act to prevent people's lives from being jeopardized: genocide, war crimes, ethnic cleansing, and crimes against humanity. In this way, the Outcome Document has become a new international legal document. China was involved in this process and made its own contribution. Thus, involvement in global or regional institutions has pushed China to clarify or develop its own thinking on human security.

Against the backdrop of the great earthquake and tsunami that devastated Japan's Tohoku region, the Ministerial Millennium Development Goals Follow-up Meeting was held under the UN framework in June 2011 in Tokyo, Japan. China sent Vice Foreign Minister Cui Tiankai to attend the meeting. In the speech he delivered, Cui, as the representative of the Government of China, stated:

To discuss the MDGs from the angle of human security offers a thoughtprovoking perspective. We believe that the MDGs and human security are interrelated and should be mutually reinforcing. The MDGs embody so many aspects of human security, while the realization of MDGs aims at greater wellbeing and security of more people in the first place. (T. Cui 2011)

Cui pointed to the fact that the general picture of global security remains disturbing: "Civilians in North Africa and the Middle East continue 
to bear the brunt of turmoil, and innocent women and children are still being displaced or killed in armed conflicts in various parts of the world." Cui concluded that:

These give rise to the call for a new concept on security and an international political order where the United Nations should play a central role. We strongly believe that the purposes and principles of the UN Charter should be upheld, and Security Council resolutions should be implemented in a faithful manner. ...In a word, if human security in the larger sense of the term is still so much threatened, there is little hope for better individual security. (T. Cui 2011)

This is an illuminating example of how China has clearly and definitively adopted and used both the idea of and the actual term "human security" in the context of a formal UN meeting. Although it was an event on MDGs and not specifically on human security, the term "human security" was explicitly employed to express China's opinion and position.

This discourse was reinforced by further developments. In February 2014, Ms. Fu Ying, Chairperson of the National People's Congress Foreign Affairs Committee, was invited to and spoke at the Munich Security Conference. She argued that the security necessary for people to survive and develop is fundamental to any security. The core of the Chinese Dream of the revival of the Chinese nation proposed by President $\mathrm{Xi}$ Jinping is to have the 1.3 billion Chinese people live a happy life. In other words, all ordinary people have the right and are entitled to live with dignity in a secure environment. This is the attraction of China's success story to the world, as well as the charm of the Chinese dream. ${ }^{1}$ This line of thinking has many elements in common with the widely shared "human security" idea. For instance, both place emphasis on individuals and their happiness, and this must be fulfilled together with national development. Ends and means should be consistent, and the persistent value is that people themselves are the end and they should not be sacrificed for arbitrary national goals.

The key point here is that China's security concept is undergoing a profound transformation. A new consensus has emerged that assumes security does not equal military security, and security should not only be comprehensive but also people-centered (yi renmin wei zhongxin): "national security" now has new connotations. 


\subsubsection{The Third Plenum ${ }^{2}$}

During the landmark Third Plenum, which was held in November 2013, a major resolution to comprehensively deepen China's reform was deliberated and passed. The long reformist document has 16 parts and 60 items. The decision to create a new National Security Commission (NSC) was announced as a component of the 13th part on the new social governance system. The purpose of the NSC is to improve the relevant institutions and strategy to better safeguard China's national security. According to the explanatory speech President Xi Jinping gave, reform and development are conditional on national security and social stability, without which reform and development cannot be advanced further. ${ }^{3}$

At present, China is faced with the dual pressure of safeguarding national sovereignty, security, and development interests externally, and maintaining political security and social stability internally (Xi 2017, 411). All kinds of risks that can or cannot be foreseen are clearly increasing, while the country's institutions and security mechanisms are insufficient to adequately meet the need of maintaining national security. This has resulted in demands to set up a powerful and capable platform to coordinate all work on national security. The responsibilities of the NSC include formulating and implementing national security strategies, advancing the construction of national security rule of law, deciding national security guidelines and policies, and studying and addressing major issues in the national security work. ${ }^{4}$ Quite understandably, this major decision drew considerable attention both at home and abroad.

In April 2014, the first meeting of the new NSC was held. According to the speech President Xi Jinping delivered, the security of the people must be its core purpose. State security should in every sense serve the people and rely on the people. The mass foundation of state security must be laid and consolidated. ${ }^{5}$ This means that state security and human security are not confrontational but rather that the two can and should coexist.

Internally, China is undergoing a modernization process and the number of contradictions is growing. In this time of rapid economic and social development, a series of social problems have been accumulating that have not been "digested" well. For some Chinese observers, "group incidents" resulting from unbalanced distribution of interests frequently break out, negatively affecting social stability. Externally, as China continues to grow, some powers and neighboring countries have been hedging against China, and as a result, contradictions or frictions in China's neighborhood have 
been increasing. Moreover, challenges to social stability and security, from home and abroad, have been affecting each other, and they are interlinked. Coping with them is becoming a more difficult job. In the current era, the concept of national security is becoming richer in depth and wider in breadth, involving a range of issues in a variety of areas. Increasingly complex problems cannot be dealt separately by foreign affairs, national defense, and security departments but rather are demanding that more agencies, social organizations, and even the whole society work together (Hu and Wang 2013).

Since the initiative to create China's NSC appears in the "social governance system" section of the November 2013 resolution, its domestic and internal security dimension is self-evident. In the meantime, the commission's work involves two dimensions (both external and internal) rather than just one. Thus the "security" the initiative refers to is of a comprehensive nature. It is not difficult to come to that conclusion if we simply recall the July 5, 2009, incident in Xinjiang, the riots in Tibet and Tibet-related self-immolations in its neighboring provinces, and the horrible killing at the Kunming Railway Station on March 1, 2014. During all these incidents, innocent people were killed or injured, and some of the incidents resulted from the actions by hostile external forces. That is why it was widely believed that internal security would be the dominant concern for China's NSC, at least in its early stage. When ordinary people can be unexpectedly harmed by violent terrorist attacks in any situation and without warning, a sense of insecurity arises, and this can be frightening. Thus, even though freedom from want is no longer a problem in today's China, ordinary people should also be able to live their lives free from fear. A broad concept of security of this kind logically became the goal for China's NSC.

In fact, as Cui Shunji of Zhejiang University points out, since the initiation of reform, at the highest levels, attention has been placed on poverty reduction, the pursuit of a sustainable development model, and China's proposals for constructing a "harmonious society" and a "harmonious world." These goals indicate that China regards the guaranteeing of basic human needs, social justice, and harmony as well as sustainable development as important parts of a continuum of national security (S. Cui 2014, 68-69). "Letting people live a happier life with more dignity" has become the goal of national development, which indicates that China's recognition of human security has been elevated to the political level. Putting people first and "governing for the people" have become the new thinking for governing the country. As a reflection of the foreign policy changes, 
handling foreign affairs for the state is shifting to handling foreign affairs for the people (S. Cui 2014). This was reinforced at the 19th Party Congress, held in October 2017, which emphasized the need to regard people's interests as paramount and let the achievements of reform and development benefit everybody more and fairly.

\subsubsection{The "Non-traditional Security" Discourse}

In China's research community, "human security" is often discussed in terms of the discourse on "non-traditional security." For years, Chinese researchers have utilized the term "non-traditional security" to distinguish the so-called non-traditional matters from more traditional matters. Traditional security usually refers to military security, namely, assuring national security through boosting military power. However, after the end of the Cold War, threats to security have increasingly come from nonmilitary domains in the form of unconventional or non-traditional security threats. Such issues include financial crises, terrorism, transnational crime, environmental degradation, the spread of HIV/AIDS, scarcity of water resources, food insecurity, and so forth.

According to the summation by a leading Chinese researcher, nontraditional security is broad-based, complex, and multi-dimensional. Examining each in turn, while traditional security falls into military, political, and diplomatic areas, and its supreme value is the pursuit of peace and the elimination of war or the possibility of war, a broad-based non-traditional security is more about economic, social, cultural, and environmental threats as well as the emerging cyber security and space issues. In addition to peace, non-traditional security relates more to risk, crisis, emergency, and daily threats to life. It relates more to natural disasters, accidents, emerging public health incidents, and major public security events.

Second, non-traditional security is complex. Threats to non-traditional security are mainly the threats to "societal security" and "human security." Society and people are the chief referent objects of non-traditional security, and a "safe China" has societal and human dimensions. For individuals, safety means that the security of people is guaranteed: namely, individuals enjoy a state of existence in which a person's body is not injured, their mind is not harmed, they are not deprived of their property, and their living environment is not undermined. 
Third, non-traditional security is multi-dimensional. According to the place and origin of non-traditional security events, threats to nontraditional security facing a country can be divided into four categories: (1) exogenous non-traditional security threats which take place abroad and chiefly require diplomatic negotiations; (2) endogenous nontraditional security threats which take place at home and chiefly require domestic interventions; (3) “bi-dogenous” (双源性) non-traditional security threats which take place in peripheral areas, necessitating both domestic and international management; and (4) “multi-dogenous” (多源性) non-traditional security threats that involve both traditional and nontraditional security issues requiring the involvement of the military in addition to other organizations (Yu 2013,3-6).

Throughout the above process of ideational transition, a few landmark crises have affected China deeply, including the 1997 Asian financial crisis that highlighted the importance of financial security, the 2003 SARS crisis that highlighted public health security, and the March 1, 2014, terrorist attacks at the railway station in Kunming, the capital of Yunnan Province. The horrible March I violence against innocent people especially highlighted the serious security threat that ordinary people could encounter in their daily lives. This genuine risk could give rise to a widespread sense of fear.

As noted, earlier conceptions of security in China were mainly focused on state security, the importance of which remained unquestioned. Now that human security has been put forward, and given its undeniable value orientation, support for the concept is gaining momentum. In fact, Chinese scholars speak highly of human security and argue that it goes beyond the limits of state-centric traditional security research and is the least traditional theory among the non-traditional security domains ( $\mathrm{Yu}$ 2014,18 ). Human security research explicitly sees people as a collectivity and individuals as the referent object of security. This transcends the dilemma of more traditional security theory, since the state can bring about insecurity to its citizens. Such a possibility raises questions concerning the relationship between state security and human security. In general, Chinese researchers do not endorse the view that human security overrides state security or that the two are confrontational, but rather affirm the reasonableness and value of state security at the same time.

For example, Shi Bin, a professor at Nanjing University, asserts that the human security idea is a focal embodiment of non-traditional security and new security concepts, and yet the relationship between human security and state security is much more complicated (Shi 2014, 97-100). Shi 
argues that both state security and human security, in terms of their security concerns and value pursuits, have legitimate claims. However, there is no reason for either of them to become totally dominant. Human security is of course the fundamental goal and ultimate value of human development. The value orientation of putting people first, with human security at the center, provides it with the moral high ground and legitimacy. However, a person has both individuality and sociality, and individuals are often weak and helpless. Resisting foreign military invasion and safeguarding national sovereignty and territorial integrity are therefore in the nation's common interest. Nonetheless, the traditional state-centric security idea and strategy indeed ignores the security needs of many non-state or sub-national entities and cannot adequately deal with external nonmilitary threats such as environmental degradation and pandemic disease.

Second, Shi Bin articulates that, although there is a tension between "human security" and "state security" and the two may conflict in practice, they can still be mutually accommodating and complementary if handled and balanced well. Therefore, this can provide a favorable opportunity for upgrading the overall security level of all entities. People's security and welfare, and the improvement of their living conditions and quality of life, are an important base for national identity, social stability, and political legitimacy. In this sense, human security and state security are not necessarily contradictory. For Shi, the human security discourse has a tangible Western value orientation bearing liberal colors; consequently, in practice, it tends to override the security interests of the sovereign state. The acclaimed paradigm shift from the state to individuals excessively downgrades the positive role of the state in dealing with various security challenges.

For Zhang Yunling of the Chinese Academy of Social Sciences, the rise of non-traditional security issues does not mean that traditional security is no longer important. The appearance of non-traditional security on the agenda and the fact that it is stressed imply that it has been included in the category of security, and therefore the formation of a "comprehensive security" concept includes both traditional and non-traditional security as well as the corresponding security policies (Y. Zhang 2012).

Taken together, with "non-traditional security" increasingly becoming part of the mainstream discourse in China, researchers tend not to deny the value of state security but rather see human and state security as being mutually accommodating. Nevertheless, the theoretical shortcomings of non-traditional security, as Guoguang Wu rightly points out, are obvious, when it is narrowly framed as oppositional to traditional security, without 
any positive and substantive defining of the contents and nature of new “securities" (Wu 2013, 5).

The relationship between state security and personal security is not a zero-sum one though. More state security does not mean less personal security, and vice versa. The goal should be a calibrated balance between the two. Moreover, the increasing tendency to securitize many issues and aspects of life may not be entirely beneficial. An overemphasis on discussions of security may imply a growth of insecurity. For example, in China food safety was previously not discussed often but was later widely talked about. This indicated that food safety was not formerly an issue, but it became such an issue. The deterioration of food safety was a negative development that involved the need for moral reconstruction in the society.

As shown above, the Chinese research community has attached increasing importance to the issue of human security. Meanwhile, they are not just following in others' footsteps, but rather have developed their own analyses and views. Some researchers have stressed that individuals are both the starting point and the ultimate purpose of any society. The emancipation of human beings should be the fundamental goal of any social emancipation. It is people who are the final objective of the concept of human security, and this is the core value any security is supposed to protect, while the state provides the means or temporary purpose (J. Li 2013, 74-75). The establishment of "people are the purpose" as a value grew to have great significance for Chinese society after the community had drawn lessons from the history of the People's Republic since 1949.

During the Cultural Revolution period, many innocent people were attacked, detained, or persecuted illegally and immorally; rights were ignored, and people were harmed. After a disastrous decade, many people reflected on their painful experiences and thought about the phenomenon of imposing horrible acts on innocent individuals, something that should never recur. In the early reform period, there emerged a movement in China's intellectual community that began to discuss the issues of humanism (rendao zhuyi) and alienation (yibua). During this time, many intellectuals affirmed the significance of humanism and argued for the promotion of human values. Some of them cautiously adopted the term "Marxist humanism" or "socialist humanism" to distinguish from the so-called capitalist doctrine. Not long after, the debate abruptly came to a halt due to a political intervention. However, along with further economic reform and considerable social development, the awareness of the value of the individual human being in China was reawakened and the value of people confirmed. The 
initiative for humanism in the 1980s was in fact later accepted by the whole of Chinese society. This was also reflected in the discussions and research on human security, since it was made clear that guaranteeing human security is the value base for maintaining non-traditional security. The protection of people and human development should be set as the ultimate goals of any security course. Obviously, this progress is precious for Chinese society and deserves appreciation by the outside world.

The paradigm of human security opposes the harming of the human freedoms and rights to promote economic growth or social stability. Nor does it favor the pursuit of economic benefits and communitarian policies at the expense of sacrificing the security and dignity of the individuals or the nation. The fundamental reason for this lies in enhancing the value of people, which is the key and ultimate goal, and there is no higher goal than this.

The previous practices of both "collective security" and "common security," Yu Xiaofeng, a leading scholar in human security, argues, could not have avoided the limitations of regarding the state as the chief actor (Yu 2014, 33). By contrast, "shared security," which he has proposed, regards the human community as occupying the central position of security, the protection of human life as the value base of security, social safety and prosperity as the priority goals of security, and harmony and cooperation as the supreme principles for security interactions between the states (Yu 2014, 33-34). This moves the discussion beyond the traditional security discourses and has the potential for further theoretical development.

\subsection{Protection ANd EMpowerment}

According to the Human Security Now report (CHS 2003) and the October 2012 resolution adopted by the UN General Assembly as a follow-up to Paragraph 143 on human security of the 2005 World Summit Outcome, as well as the definition and design of this book, human security has two dimensions: protection and empowerment. In China, the dimension of protection has drawn much attention, epitomized in the doctrines of "putting people first" (yiren weiben) and "diplomacy serving the people" (waijiao weimin), which I discussed in a detailed way in an earlier study (Ren and Li 2013). The findings from this earlier study have been reinforced by recent evidence. For example, a Chinese newspaper correspondent wrote of his impressions when reporting from the National People's Congress (NPC) sessions. He was deeply impressed by the attention the NPC delegates paid to the concrete issues concerning 
people's daily lives, including social insurance, income distribution, rights of peasant workers, food safety, unreasonably high drug prices, and protection of stakeholder interests. In his view, those kinds of issues had never before been so meticulously discussed at the NPC (Yuan 2005 ). The changes the correspondent detected indicate ongoing healthy trends in human security terms.

A harmonious society is one that puts people first, which means people's everyday life is a priority for the society. A government that puts people first is a government that represents people's interests. Economic and social development should put human development at the center, and human development is the ultimate value judgment for social progress (Yuan 2005). Meanwhile, the achievement of human security is a cooperative venture between the individual, society, and the state (Bedeski 2013, 29). Government as a "necessary evil" is very much a Western invention and is not a Chinese idea. Traditionally, people in China often have wishes for their government, and they want it to do good things for them. Compared to Western political culture, they have less vigilance but higher expectations of the government. One revealing example is the use of the term "parent officials" ( fumu guan) to refer to government officials, with people expecting them to play a paternalistic role. Without cooperative ventures, human security cannot be achieved.

On the protection side, while people-oriented ideals might be considered noble ones, challenges come from the process of implementation. Not surprisingly, many problems are persistent. One prominent example is the matter of government land appropriation and relocation of residents. Sometimes the failure to protect the rights and interests of the ordinary people has led to acute standoffs and conflicts, and in some cases even extreme acts of protest. When property development businessmen and arbitrary power coalesce, together they can undermine the interests of the ordinary people who are affected. Protecting people's legitimate interests has become an outstanding issue in China's human security amid the drastic social changes and urbanization of recent decades.

Moreover, the Chinese leadership came into office with a promise to narrow the widening gap between rich and poor, and to shift to a more environmentally and economically sustainable growth model. Since gross domestic product (GDP) became the brand of accomplishment for many government officials, "GDP worship" has prevailed. Local officials tended to initiate projects that show their "achievements" and promote their image to the public. When poorly planned, such projects led to unexpected 
outcomes and environmental damage. When this became obvious, a strategic shift had to be undertaken. "No GDP growth at the expense of the environment" is becoming a new norm and "ecological civilization" the new banner, which was again stressed in the 19th Party Congress Report of October 2017.

The reform era has been characterized by remarkable success in terms of rapid economic growth and the improvement of living standards. After three decades of successful economic development, the country is standing at a new starting point. If the ruling party's historical promise to "let some people get rich first and eventually arrive at common prosperity" was a prerequisite for the reforms to unfold, and if four decades later this historical task has been basically fulfilled, what the reform enterprise must accomplish now is the other half: namely, to realize a common prosperity. This is a goal that will justify and inform further reforms. The reaffirmation of realizing common prosperity in line with the principles of governing for the people and building a comprehensive and balanced well-off society will guide future reform with a clear direction. ${ }^{6}$ To fulfill its pledge to narrow the gap between rich and poor and to "unwaveringly pursue common prosperity," the leaders have to place the people in their hearts and take their needs seriously in order to realize the goal of the "Chinese dream." After the 18th Party Congress in 2012, the new General Secretary $\mathrm{Xi}$ Jinping expressed his view that "to fulfill the people's desire for better lives is what we shall strive for." 7 This statement sounded dear and close to the ordinary Chinese people.

On the empowerment side, there have also been several measures. Only when a person has the capability for survival and development can he or she enjoy real freedom. The capacity for development is what empowers an individual. Thus, a modernized China should not only accept empowerment through protection but also appreciate its importance in realizing human freedom and guaranteeing human security. Education as a right is the fundamental and most significant form of empowerment, as the human experience has repeatedly revealed. Thus, educational development is a significant way to empower people, especially compulsory education. China has reason to be proud in this regard. It has a tradition that puts significant emphasis on education, in which parents always try their best to pave the way for their children to receive a good education, and often they are willing to make sacrifices. In China, nine-year compulsory education has been in force for years. In 1989, Project Hope was set up as an educational support supplement, which later became well known throughout Chinese 
society. It was initiated by the Central Youth League and the China Juvenile Development Foundation as a philanthropic enterprise to help less developed areas to establish primary schools, to financially support children who have dropped out of school in the poorer regions to return to school, and to improve education in rural areas. The project received society-wide attention and support. Implemented successfully, the project has positively changed the fate of hundreds of thousands of children of poor families and has also beefed up the whole society's awareness of the importance of education, thereby improving China's fundamental education.

As a major initiative for the future, the Third Plenum set the aim of modernizing China's governance system and governing capability, a longterm goal for China. An important part of it is to reshape a new social governance system. During the 2014 National People's Congress session, President Xi joined the Shanghai delegation for a deliberation of the government's work. For him, the key to future social governance is institutional innovation, and its core lies in people. Only when people are living harmoniously can society be operating in a stable and orderly manner. For Han Zheng, the party secretary of Shanghai, social governance was up to everybody, and the governing process should serve the all-round development of people. Rule of law is the foundation of social governance, without which there can be no base for long-standing good governance and robust stability. ${ }^{8}$ For that matter, among other things, it is necessary for grass-root cadres to regard people's concerns as their own matters, while always trying to understand their feelings and demands. Again, the key challenge is to make this happen in real life. Fortunately, in China there have been local autonomous grassroots organizations that play an intermediate role and serve to help in addressing problems at the grassroots level. They assist ordinary people who encounter difficulty, and they also, for example, mobilize donations to help people in the regions that have been struck by earthquakes or other natural disasters. The work of these local self-help organizations has proved to be useful and reassuring in terms of social governance.

\subsection{Prominent Human Security Threats ANd the Chinese Responses}

Since 'human security' is central to non-traditional security, it is concerned with all kinds of factors that directly threaten human security" (Zhou 2012, 255-256). In today's China, prominent direct threats 
include air pollution, food safety, and cyber security. This section examines each of these in turn.

The seriousness of the problem of air pollution first became apparent right all across China in 2013. Heavy smog emerged not only in North and Northeast China but also was reported in other regions. Many people were alarmed by the situation, including concerns expressed by China's neighbors, Japan and South Korea. The spread of the smog made it obvious that the environment in which people were living was deteriorating, a red-light signal providing a warning on the existing pattern of economic growth, which was consuming a great amount of energy and yielding considerable waste. While many people were already aware of the issue, the shocking reality of the situation in 2013 and its related risks served to awaken people as never before. With many people walking in the streets wearing masks, the sense of insecurity was palpable and imminent. In this context, the specific threat of air pollution became the number one threat to people's security.

To cope with this threat, in June 2013, China's State Council laid out ten measures to prevent and combat air pollution. As a follow-up, in September, China released an Action Plan to implement this, which was a blueprint to fight against air pollution by 2017. Since then, further work has been undertaken. In his Government Work Report delivered in March 2014, Premier Li Keqiang swore to "fight pollution like fighting poverty." When he was looking around the city of Beijing, President Xi emphasized that the sprawling pattern of urban development had to be contained and steps should be taken to deal with smog pollution and improve air quality. Among the five requests $\mathrm{Xi}$ made, one was logically to reinforce the measures to rein in air pollution. The top priority to combat air pollution and improve air quality was to control PM2.5, with major steps that included reducing the burning of coal, strictly limiting growth in the number of cars, adjusting industries, tightening management, and executing joint prevention and control. ${ }^{9}$ Xi's move clearly sent a signal that the government was committed to taking measures for better air quality.

The Chinese leadership had previously pledged to launch a revolution in energy production and consumption and said that urbanization must be balanced with ecological security (Hook 2012, 1). However, pollution was worsening and was posing a serious threat to human health and social stability. To reduce air pollution and carbon emissions, Beijing (population 20 million) is attempting to phase out coal-fired power plants within the city's urban core, replacing them with cleaner-burning natural gas 
power plants. These measures are also basically valid for other cities. After all, fighting pollution is relevant to everybody's security, a point that has attracted a high-degree of consensus within Chinese society. Similarly, China's energy sector had a watershed year in 2013. Reforms that could have a profound impact on China's environment and energy policy were floated. With concerns over air pollution mounting throughout the year, the country is poised to shift away from its reliance on coal and toward use of cleaner forms of energy, including natural gas. Shale gas exploration is making progress in the country. Driven by crises, a true transformation is under way but surely will take time to complete.

The second human security concern among the Chinese people is that of food safety. In recent years, a series of food contamination incidents occurred throughout the country, causing serious concern. A 2010 poll by Xiaokang (小康 [Moderately Well Off]) magazine and Tsinghua University conducted in 12 Chinese cities found that food safety ranked number one of all social concerns among those surveyed, reflecting mounting anxiety after the 2008 melamine crisis (Z. Zhang 2010; Wishnick 2013, 256). Within this context of growing concern over food safety, the government has not been unaware or insensitive. Appearing at a press conference, Premier Li Keqiang responded by stressing that "food safety is of utmost importance." 10 Answering a different question concerning the missing MH370 aircraft, he stressed that "any case involving human life has to be treated with the utmost care" (renming guantian). As with the issue of air pollution, the 2014 Government Work Report promised to adopt the strictest surveillance, the most severe punishment, and the most serious accountability measures to resolutely govern pollution at the meal table and reassure people of "security on the tongue tip" (K. Li 2014). In fact, there is a widely shared consensus in China on the need to make efforts to ensure food safety.

Specialists distinguish between two separate food-related issues: the first is related to food security or ensuring sufficiency in the quantity of food; the other concerns food safety, which refers to the quality of food. While the former involves the question of whether there is sufficient overall provision of food, an area in which China has vowed to "hold the bowl firmly in our own hands," the latter involves the question of whether people can be assured that the food they eat every day is safe. Formerly, the issue of food scarcity trumped food safety. But today the main problem in China lies in food safety, with people alarmed by reports of different kinds of contamination. 
In recent years, this has even spilled over into China's foreign relations, and was epitomized in the spoiled jiaozi (dumpling) incident between China and Japan. The incident originated in Hebei Province. An employee in the Tianyang food factory was resentful over his low income. In revenge, he deliberately poisoned jiaozi, and the contaminated products were exported and sold in Japan. Some customers bought and ate them, becoming ill. On investigation, pesticides found in the frozen dumplings were traced back to China. This was a single case of a crime that resulted in grave consequences. The reputation of China's food products was seriously damaged, and the Sino-Japanese relationship was also somewhat affected. This incident once again highlighted the close links between domestic and international affairs.

In the final analysis, the root cause lies with individuals, and the issue of "moral collapse" has been used to refer to this situation. To what extent this is true can be debated. There was a belief that overuse of fertilizers and pesticides was rampant, and that growers distinguish between what they themselves eat and what is sold in the market, even if they know the latter is not suitable to be eaten. Again, how widespread the phenomenon is can be discussed, yet reports on these kinds of practices result in people feeling that the food they eat may be unsafe.

As a result, in China there was an obvious lack of public trust in food safety. Tighter regulations must be implemented. Greater transparency helps to build public trust, including more official data and statistics about the improvement (or deterioration) in food safety, increased freedom for media and civil society to verify the official data, more effective actions from the government in handling the corruption and malfeasance involved in food safety issues, stronger protection for whistle blowers who uncover production of unsafe food and, more importantly, removal of the corrupt officials involved. Further measures must be taken to improve China's food safety regulations, consumer education levels, and supply chain traceability and sustainability.

The third and final issue is that of cyber security. The use of the internet has increasingly become a part of everyday life in China. By 2013, there were over 600 million internet users in the country, and mobile internet users reached 461 million, making the community of Chinese "netizens" (wang min) the world's largest. With this growth, cyber security has become a prominent issue. In fact, China is one of the major victims of cyber-attacks. The covert activities revealed by Edward Snowden highlighted the vulnerability of nations and individuals who are monitored 
illegally and immorally (Meng 2014). At the government level, a Central Small Leading Group on Cyber Security was created, which held its first meeting in February 2014. It was emphasized that cyber security involved national security and development, as well as the careers and everyday lives of a vast number of ordinary people. It was therefore a major strategic issue. ${ }^{11}$ The breakdown and vulnerability of the internet can have a widespread impact on people and their lives.

\subsection{Conclusions}

This chapter has addressed the three research questions the research project raised by elaborating on how the idea of human security is understood or defined by the government and social actors, the ways in which the distinctions between the "protection" and "empowerment" aspects of human security are understood and accepted, and what downside risks are perceived as pressing human security issues in China. The major ones discussed here included air pollution, food security, and cyber security.

As has been indicated in this chapter, although human security as a term is not frequently used, there have been various human security practices in China. The idea of human security has been firmly established and threats to human security have been detected. Such problems result from China's still unfinished process of industrialization, urbanization, and drastic social change. The good news is that progress is being made, and theoretically, globally accepted values often exist at the individual level. With this comes occupancy of the moral high ground. China has gone far beyond the lip service level of cheaply talking about people's interests. This deeper approach can be fully integrated into human security in its holistic sense. Threats to human security can be domestic risks, yet they often are transnational ones such as air pollution and sand storms. They require different sectors of the society and neighboring countries to work together.

Over 20 years ago, the Commission on Global Governance drafted a report that emphasized the distinction between the security of states and the security of peoples (CGG 1995). Twenty plus years later, the security of peoples has gained momentum. This is also true in China, the most populous country in the world. China's practices have considerably reinforced the overall trends of affirming the value of people, protecting their lives, ensuring their legitimate interests and dignity, and empowering them not only to survive but also to live a respectful life. What is happening in China is indicating a healthy trend in this direction. 


\section{Notes}

1. "Fu Ying Attends the Munich Security Conference," see http://www. fmprc.gov.cn/ce/cehu/hu/zgyw/tl128210.htm

2. Each year the Communist Party of China Central Committee holds an annual plenum to deliberate what it believes to be the most important issues.

3. For the full text of the Resolution and Xi's explanation, see Renmin Ribao, November 13, 2013.

4. Ibid.

5. See Renmin Ribao, April 16, 2014.

6. "Editorial," Ershiyi shiji jingji baodao [21st Century Economic Report], October 16, 2003, 2.

7. Xi's remarks at the closing of the 18th Party Congress in November 2012.

8. See Wenhui Bao [Wenhu Daily], March 7, 2014, 1.

9. Renmin Ribao, February 27, 2014.

10. Li's remarks at the 2013 National People's Congress press conference held in March.

11. Renmin Ribao, February 28, 2014, 1.

\section{REFERENCES}

Bedeski, Robert E. 2013. Anthropocentric Theory of Human Security. In China's Challenges to Human Security - Foreign Relations and Global Implications, ed. Guoguang Wu, 28-53. London/New York: Routledge.

Breslin, Shaun, and Xiao Ren. 2018. China and Global Governance. In International Organization and Global Governance, ed. Thomas G. Weiss and Rorden Wilkinson. London/New York: Routledge.

CGG (Commission on Global Governance). 1995. Our Global Neighborhood: The Report of the Commission on Global Governance. Oxford: Oxford University Press.

CHS (Commission on Human Security). 2003. Human Security Now. New York: Commission on Human Security.

Cui, Tiankai. 2011. From Commitment to Concerted Action. Remarks by Vice Foreign Minister Cui Tiankai of China at the Ministerial Follow-up Meeting, 2 June 2011, Tokyo, Japan. http://www.fmprc.gov.cn/eng/wjdt/zyjh/t827392. shtml

Cui, Shunji. 2014. Ren de fazhan yu ren de zunyan: Zaisi ren de anquan gainian [Human Development and Human Dignity: Rethinking the Concept of Human Security]. Guoji Anquan Yanjiu [Journal of International Security Studies] 1: 63-77. 
Hook, Lesley. 2012. Battle to Balance Urbanization with Ecological Sustainability. Financial Times Special Report-China, December 12: 1.

$\mathrm{Hu}, \mathrm{Hao}$, and Wang Dong. 2013. Ruhe kandai sheli guojia anquan weiyuanhui [How We Should Perceive Creating the National Security Commission]. Liaowang xinwen zhoukan [Liaowang News Weekly], November 18: 30-31.

ICISS (International Commission on Intervention and State Sovereignty). 2001. The Responsibility to Protect. Ottawa: The International Development Research Centre.

Kent, Ann. 2014. China's Participation in International Organizations. In Power and Responsibility in Chinese Foreign Policy, ed. Yongjin Zhang and Greg Austin, 132-166. Canberra: Asia Pacific Press.

Kim, Samuel. 1999. China and the United Nations. In China Joins the World: Progress and Prospects, ed. Elizabeth Economy and Michel Oksenberg, 42-89. New York: Council on Foreign Relations.

Li, Jia. 2013. Ren de anquan: Fei chuantong anquan nengli jianshe de xinshijiao [Human Security: A New Perspective on the Non-traditional Security Capacity Building]. In Zhonggno fei chuantong anquan nengli jianshe [Non-traditional Security Capacity Building in China], ed. Yu Xiaofeng, 106-121. Beijing: Zhongguo shehui kexue chubanshe.

Li, Keqiang. 2014. Zhengfu gongzuo baogao [Government Work Report]. Renmin Ribao [People's Daily], March 14.

Meng, Wei. 2014. Wangluo anquan: Guojiazhanlue yu guoji zhili [Cyber Security: National Strategy and International Governance). Dangdai Shijie [Contemporary World] 2: 46-49.

Morton, Katherine. 2009. China and the Global Environment: Learning from the Past, Anticipating the Future. Sydney: Lowy Institute for International Policy.

Ren, Xiao, and Yanxing Li. 2013. A Return to People: China's Approach to Human Security. In New Approaches to Human Security in the Asia-Pacific: China, Japan and Australia, ed. William T. Tow, David Walton, and Rikki Kersten, 31-42. Farnham: Ashgate.

Shi, Bin. 2014. 'Ren de anquan' yu guojia anquan ['Human Security' and National Security]. Shijie Jingji yu Zhengzhi [World Economics and Politics] 2: 85-110.

UNGA (United Nations General Assembly). 2012. Resolution 66/290. Follow-up to Paragraph 143 on Human Security of the 2005 World Summit Outcome. New York: United Nations.

Wishnick, Elizabeth. 2013. Food Security and Food Safety in China's Foreign Policy. In China's Challenges to Human Security - Foreign Relations and Global Implications, ed. Guoguang Wu, 245-260. London/New York: Routledge.

Wu, Guoguang. 2013. Human Security Challenges with China. In China's Challenges to Human Security - Foreign Relations and Global Implications, ed. Guoguang Wu, 1-27. London/New York: Routledge.

Xi, Jinping. 2017. The Governance of China II. Beijing: Foreign Languages Press. 
Yu, Xiaofeng. 2013. Fei chuantong anquan zhili yu 'hemei zhongguo' [Nontraditional Security Governance and a 'Safe China']. In Zhongguo fei chuantong anquan yanjiu baogao, 2012-2013 [Report on China's Non-Traditional Security, 2012-2013], ed. Yu Xiaofeng, 1-50. Beijing: Shehui kexue wenxian chubanshe.

2014. Gongxiang anquan: Fei chuantong anquan yanjiu de zhongguo shiyu [Shared Security: A Chinese Perspective on the Study of Non-Traditional Security]. Guoji anquan yanjiu [Journal of International Security Studies] 1: 4-34.

Yuan, Xialiang. 2005. 'Ren' de daxie ['People' Amplified], Wenhui Bao [Wenhui Daily], March 8: 3.

Zhang, Zhiwei. 2010. Food Security Tops People's Concern in Survey. China Daily, June 30. www.chinadaily.com.cn/china/2010-06/30/content_ 10042303.htm.

Zhang, Yunling. 2012. Preface. In Zhongguo fei chuantong anquan yanjiu baogao, 2011-2012 [Report on China's Non-Traditional Security Studies, 2011-2012], ed. Yu Xiaofeng, 1-4. Beijing: Shehui kexue wenxian chubanshe.

Zhou, Jiehong. 2012. Zhongguo shipin anquan wenti yu qushi [Food Security in China: Issues and Trends]. In Zhongguo fei chuantong anquan yanjiu baogao, 2011-2012 [Report on China's Non-Traditional Security Studies, 2011-2012], ed. Yu Xiaofeng, 254-276. Beijing: Shehui kexue wenxian chubanshe. 